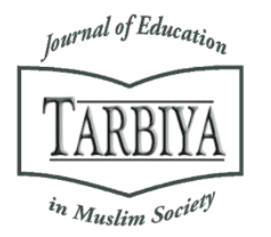

Available online at TARBIYA: Journal of Education in Muslim Society Website:

http://journal.uinjkt.ac.id/index.php/tarbiya

TARBIYA: Journal of Education in Muslim Society, 3(2), 2016, 186-204

\title{
EDUCATION NONVIOLENCE THROUGH CHILD FRIENDLY SCHOOL
}

\author{
Zaenul Slam \\ Syarif Hidayatullah State Islamic University of Jakarta, Indonesia \\ E-mail: zaenul_slam@yahoo.com
}

Received: $05^{\text {th }}$ October 2016; Revised: $10^{\text {th }}$ November 2016; Accepted: $22^{\text {th }}$ December 2016

\section{Abstract}

This research described the education nonviolence through implementation of child friendly school in Junior High School 3 Majalengka, West Java Province. The research was qualitative. The data were collected through observation, interviews, and documentation. The subjects of the research were the principal, teachers, and students. Analysis of the data were through the three stages: data reduction, data presentation, and conclusion. Validity test of the data used triangulation sources. The results show that education nonviolence had established the education to a peace culture, to create and encourage the peace in the minds of the students based on the universal values of respect for life, liberty, justice, solidarity, tolerance, human rights and equality between them. Education nonviolence through implementation of child friendly school in Junior High School 3 Majalengka was seen from the success of school management.

Keywords: education; nonviolence; implementation; child friendly school; junior high school majalengka

\section{Abstrak}

Penelitian ini memeberikan gambaran tentang pendidikan tanpa kekerasan melalui penerapan sekolah ramah anak di Sekolah Menengah Pertama (SMP) 3 Majalengka, Provinsi Jawa Barat. Penelitian ini adalah kualitatif. Data dikumpulkan melalui observasi, wawancara, dan dokumentasi. Subjek penelitian ini adalah kepala sekolah, guru, dan siswa. Analisis data dilakukan melalui tiga tahapan: reduksi data, penyajian data, dan kesimpulan. Uji validitas data menggunakan sumber triangulasi. Hasil menunjukkan bahwa pendidikan tanpa kekerasan telah membentuk pendidikan ke budaya perdamaian, untuk menciptakan dan mendorong kedamaian di dalam pikiran siswa berdasarkan nilai-nilai universal penghormatan terhadap kehidupan, kemerdekaan, keadilan, keakraban, toleransi, hak asasi manusia dan kesetaraan di antara mereka. Pendidikan tanpa kekerasan melalui penerapan sekolah ramah anak di SMP 3 Majalengka dilihat dari kesuksesan manajemen sekolah.

Kata kunci: pendidikan; tanpa kekerasan; penerapan; sekolah ramah anak; SMP Majalengka

How to Cite : Slam, Z. (2016). Education Nonviolence Through Child Friendly School. TARBIYA: Journal of Education in Muslim Society, 3(2), 186-204. doi:10.15408/tjems.v3i2.4983.

Permalink/DOI: http://dx.doi.org/10.15408/tjems.v3i2.4983 


\section{Introduction}

All components must be convinced and showed no doubts about the need for nation and character building by Ir Soekarno, the First President thematized the nation and character building because constitutionally that commitment has been expressly stated in the fourth paragraph of the Preamble of the 1945 Constitution Indeed, this commitment is the crystallization of the national spirit that has historically crystallized in the form of National Revival Movement, 1908, the Youth Pledge October 28, 1928, which culminated with the proclamation of Indonesian independence August 17, 1945 (Winataputera, 2012: 33). This proposition is reinforced by Budimansyah (2010: 1) which states that "nation-building and character development are the two main things that need to be done nation Indonesia in order to maintain its existence, both as if they were two sides of the same coin". Nation building must be in unison with the character development and vice versa. It is also implicit in the lyrics of our national "rise up and build his soul for Indonesia was better". Building the spirit is to build the character of men and nations. Therefore, the turmoil of all components of the nation's perceived alarming condition today and the prospect of the nation of Indonesia in the future it is reasonable that the development of the nation and the character is a need for the present and future of the Indonesian nation.

Education nonviolence is an integral part of nation and character building especially after we watched it clear that acts of violence by man in nearly all the world. As in Indonesia on cases of violence and conflict that characterizes the Indonesian nation trip, especially in the late 1990s, of the bloody conflict in Sambas, Sampit, Ketapang, Ambon, Poso to other regions in Indonesia. Similarly, the radicalism of certain people that religion often use violence as a means to achieve its goals, such as bomb threats, arson, and so, of course, require precise handling. In fact, much has been done to prevent these conflicts, from seminars about finding a solution to the conflict dialogues between religious leaders of different hither to conflict-based violence still occurs.

Education nonviolence is the most effective to prevent and to eliminate acts of violence. Through this educating, it is hoped the spirit of nonviolence will flow in the blood of every young generation and reflected in daily actions. The emergence of a new generation of unviolence is expected to break the culture of violence that still stands strongly. Giving education for nonviolence from an early age is one of the solutions to anticipate the completion of the Indonesian community violence. Through The educating for nonviolence expected in the next generation to understand, analyze, address the problems faced by the people associated with violence and can build a life of un-violence on an ongoing basis, consistent rooted in the values of Pancasila so that the ideals of the nation can be realized lasting peace. Sigit (2010) reckons that through the education nonviolence is expected to give a glimmer of hope that the younger generations, especially children to become good citizens, peaceful loving others devote themselves to the un-violence. Therefore, education nonviolence indicate a learning process and cultivation of mental attitudes that promote positive values of nonviolence in the face of every socio-religious issues in society. Education is certainly bury deep in the egoistic attitudes, but instead promote the interests of the whole community rather than those of individuals or groups to achieve a state of harmony among members of the public.

Education nonviolence actually can be performed anywhere, either at school, the family and in society. But the education nonviolence 
would be more effective if done in school. The involvement of schools in the prevention of violence have a strategic and anticipatory position. This is where parents entrusted their children for students to become people who are successful and useful for religious, parents, community, nation and state. All parents hope for the future of their children handed over to the school. As is often delivered layman when his transfer to the school, we submit our children to school because we are not educated (Elfindri etc, 2010: 1)”. According to Lickona, (1991: 20) that the school as a vehicle for moral educator / characters are vital at the time of the weakening of the value of education in society. Mulyasa (2010: 62) states that the school is authorized very freely as a vehicle for fostering and developing the character. Therefore, the school has a foundation and broad support to educating for un-violence.

Various parties actually believe and do not show any doubt that the school is the best vehicle for un violence education but can not be covered that in fact a variety of violent behavior towards children is still in progress at the school involving the school community. especially teachers and students is a matter of public consumption. Even though the incident does not represent the face of education in schools, but the embarrassment is like a drop of indigo broken milk pot. Kunaepi (2012: 3) says that until now, the noble ideals of education in Indonesia is often inversely proportional to the amount of violence in schools and educational activities. The results of the study Indonesian Child Protection Commission in 2013 which reveals that violence against children school environment that teachers with a frequency of 2039 cases $(29.9 \%)$, a classmate with a frequency of 2871 cases $(42.1 \%)$, and another friend frequency class with 1902 cases (27.39\%). Tilaar (2002: 326) says that the circumstances of the adult school is just over a prison for learners.
Suharno (2013: 3) says the violence that occurred as mentioned above, a marker that the atmosphere of the school which ideally is a process of acculturation and cultivation not been ideal. Even the violence that is done by a child can be said is a testament not smooth the role of schools as a medium for creating a civilized society and oriented towards peace and abandon violence instruments in a variety of humanitarian and social relationships.

Based on the problems above was mention that school of functions should be returned to its function as a fun, healthy, safe, and friendly to everyone. Ki Hadjar Dewantara, Mr Indonesian Education reckons that the school as a garden for students. The concept of this park is an association of public green spaces, airy, spacious, making it a convenient place to bet and learn. Park means a playground, shady, quiet, and of course fun. Children are always excited and happy to spend time in the garden. To make school more fun, She introduces "The Among System", which is a method of learning that is based on the concept of love, care and dedication based on love." Based on The Among system based on things: the natural conditions and freedom. That is an education in these schools should be able to restore the student as an independent human being, so the school is an effort to build the student to become a man of faith and devoted, inner and outer independence, noble character, intelligent and skilled, as well as physically and mentally healthy. Tilaar (2002: 242) suggests that function of schools should be transformed into an arena for dialogue between teacher-studentparent and people who have the school. School is not an institution indokrinasi, because if so function means the death of culture". Similarly, the school is not a playground where students have the freedom to develop its natural. School is actually a vehicle for liberation from magma that is in each individual in order to obtain the right 
direction, given by the environment as well as leaders, and the guidance given by teachers with great affection. The Ministry of Education and Culture (2015: 3) reckons that schools should be encouraged to be a place to hone, to love and care for students. Schools also need to be encouraged to continue to improve ourselves in order to maximize its function as a learning space and vehicle interaction of various human cultures and religions, so that the school really becomes a place that can accommodate all of the elements regardless of the status of religion, race, culture, social status, economic status, and type of intelligence or ability of the students. If so, then the school will be a pleasant home; teachers will be a good parent who always missed his presence; while students become children always miss school and attendance of teachers and other school communities.

There are still quite high gap between the demands of the ideal school in its function as a vehicle for education now. Thus the need to realize the character of the school as a vehicle for education unviolence increasingly felt and urgent. Moreover been set out clearly in Regulation of the Minister of Education and Culture number 82 of 2015 on the prevention and control of violence in the school. Regulation is in accordance with Nawacita President Jokowi-JK, that the state must be present to give protection to children, and intervene against violence. By Regulation of the Minister of Education and Culture number 82 of 2015 the school should be a fun place for kids, is like they are out in the garden. The children will certainly feel at home in the garden. Lickona (1991: 187189; 220-221) reckons that there are 11 principles of character education in order to be able to run effectively in school: 1) develop universal values base as a foundation; 2) define character comprehensively spanning thoughts, feelings and behavior; 3) use of a comprehensive approach, deliberate and proactive; 4) create a caring school community; 5) give the students a chance to act morally; 6) create academic curriculum meaningful and respects all learners, to develop positive qualities and helps students to succeed; 7) motivate students; 8) involving the school community as a learning community and moral; 9) to grow together in the moral leadership; 10) Involve the family and community members as Mitera; 11) evaluating the character of the school, the school staff functions as an educator of character, and the extent to which students manifest good character.

In addition, the demands expected competencies of the 21 st century can not be denied that the school must restore their function as a vehicle for character education based on the results of research Ibrahim (in Slam, 2015: 136) at Harvard University USA who explained that the success of one's life is not determined solely by knowledge and technical abilities (hard skills) that arise from education, but rather by the ability to manage themselves and others (soft skills) which includes character. The results of this study revealed that the success of one's life is determined about $80 \%$ by character / soft skills and the rest by the hard skills. Even the most successful people in the world could do much more supported by the soft skills of the hard skills. Danil Logeman famous in his book Multiple Intelegences, and emotional intelligence (Adisusilo, 2012: 81; Slam, 2015: 29), reckons that the success of one's life was $80 \%$ determined by soft skills/character (emotional intelligence, social intelligence and spiritual intelligence) and only $20 \%$ is determined by its intellectual wit.

The various models of school that can realize the ideal of the school as a vehicle for education nonviolence, one of which is child friendly school program. The child friendly school program can be defined as a school that upholds the rights of the child as a person who 
should be in the learner with a good feeling and character. Lestariningrum (2015) reckons that child friendly school program is trying to put the child in position by promoting the full protection of the rights of the child". Ministry of Education and Culture (2015: 13-14) referred if the value is more child friendly school program can be realized, that is: The first, respect the rights of every student when expressing his views on everything, especially about science, technology, art, and culture, so that students feel comfortable and fun in the learning process in schools. The Second, guarantees every student the opportunity to enjoy the education without discrimination on the basis of disability, gender, ethnicity, religion, intelligence, and background of the parents. The third, develop a school that is safe, clean, and healthy, caring and civilized environment, able to guarantee, meet, respecting the rights and protection from violence, discrimination, and treatment of other unnatural, and ensure the participation of students in planning, policy, learning, oversight and complaint mechanisms related to the fulfillment of the rights and protection of students in the study. The Fourth, implement the curriculum and teaching methods that are friendly for students (student centered teaching) with emphasis on the values of love, compassion, empathetic, sympathetic, exemplary, responsibility, and respect for students.

The purpose of this study was to describe the education nonviolence through implementation of child friendly school program in junior high school 3 Majalengka West Java Province. Indicators the child friendly school program is the school's policy on child friendly school program, have health and facilities programs, the environment and infrastructure is safe, comfortable, healthy, and clean, and accessible that corresponding the National Standard of construction and building, presence of the child participation, the bulding of values and cultural arts, have teachers and education personnel who are trained, have the safety program in schools, and their community and the business of community in the school.

\section{Method}

This research was conducted at the Junior High School 3 Majalengka West Java in the academic year 2015 / 2016. The method used in this study is a qualitative method. Qualitative research methods is the research methods used to examine the condition the object of nature (as his opponent was an experiment) where the researcher is a key instrument, data collection techniques performed triangulation of data (combined), data analysis is inductive, and qualitative research results further emphasize the significance of the generalization (Sugiyono: 2003: 8). In qualitative research data collected generally in the form of narrative, descriptive, in the words in the meticulous, personal documents, court records, artifacts, official documents and video-tapes, transcripts (Moleong, 2007: 35). Sources of data obtained through the principal, assistant principal, the coach for the school health, teacher of citizenship education. Data collection procedures in qualitative research involves four basic types: observation, interviews, documents, and the visual image (Creswell: 2002: 143). In the data collection as the main researcher, assisted by the teacher to maintain the validity of the data. This study uses a triangulation technique. Interest triangulation used by qualitative researchers is to cross check data obtained from the field. Data analysis done of qualitative analysis. A phenomenon that seems to be asked and developed through in-depth interview to the informant. In this study, data analysis is the effort made by working with the data, organize data, sorted them into units that can be managed, synthesize, search and find patterns, 
find what is important and what is learned, and decide what can be told to others (Bogdan \& Biklen, 1982; in Moleong 2007). Data analysis was performed in three inter-related activities, namely: data reduction, data display, verification to draw conclusions. The research process is presented by tahaptahapnya, namely: pre-field phase, phase activity, phase field, and field Post.

\section{Results and Discussion}

Character education actually had grown since Junior High School 3 Majalengka was established, but the child friendly school program began to appear in the academic of 2015/2016. Therefore, the education nonviolence through implementation of child friendly school program in this school began effectively realized this year. This study was started with two questions, 'what is education nonviolence' and 'how is the education nonviolence realized through the implementation of child friendly school program in Junior High Shool 3 Majalengka'.

The first question was required to answer what education nonviolence was. To facilitate our understanding of education nonviolence needed to be clarified deeply about the meaning of education. As stated in Law No. 20 of 2003 on the National Educational System, Article 1, paragraph 1 that, education is a conscious and deliberate effort to create atmosphere in learning and in the learning process so that learners are actively developing the potential for him to have the spiritual power of religion, self-control, personalities, intelligences, noble character, and skills needed by society, nation and state. According to Sapriya (2007: 105), he said that, the character has a meaning of psychological or psychiatric nature as they relate to aspects of personality, morals and manners, temperament, character, quality properties that distinguish one person to another or peculiarities that may became someone reliable than others. Beside it, Soedarsono (2009: 170) defined that, the character is as a set of values embodied in a system of fighting power (thrust) that underlies the thinking, attitudes, and nonviolent behavior. The Minister of Education and Culture (2015: 4) reckoned that, violence is an act to intimidate and coerce an individual or weaker groups to do something against their will, with the intent to harm the physical, mental or emotional. Various acts of violence that occurred in the school such as a twisted, pinching, kicking, hitting, punishing to fall ill, fainting, wounding, physical violence other, compared with siblings / other children would shout out loud and rude, insulting in front of friends / others, called stupid, lazy, mischievous, and so forth, branded as bad / evil, and other psychological violence. Nonviolence can be interpreted not perform actions intimidate and coerce an individual or weaker groups to do something against their will, with the intent to harm the physical, mental or emotional, such as: no tweaking, no pinching, no kicking, no hitting, not punish until children fell ill, fainting, wounding, physical abuse others, does not compare with siblings / other children, do not yell out loud and rude, insulting front of friends / others, not to mention stupid, lazy, mischievous, and so forth, not to label as bad / evil, and other psychological violence.

The understanding of education nonviolence can be seen from an interesting quote from UNESCO which stated that, disputes maybe inevitable, but violence is not. To prevent continued cycles of conflict, education must seek to promote peace and tolerance, not fuel hatred and suspicion disputes may be avoidable, but the violence can. To prevent the occurrence of a continuous cycle of conflict, education must seek to promote peace and tolerance, rather than burning hatred and suspicion. This quote indicates that efforts to minimize and even to prevent conflict is 
education. Therefore, education nonviolence is a conscious and deliberate effort to bring peace and tolerance, rather than burning hatred and suspicion. Another purport is that educating for nonviolence in an effort to minimize and even prevent social conflict. Through education against violence at school is expected to be embedded values of peace or nonviolence in the pupils so that they in turn can promote these values in all aspects of life in society without seeing barriers cultural, religious, racial, group, and others.

Further, this study talked about what was exactly meant with the Child Friendly School program. The word school is a language derived from Latin: skhole, Scola, scolae, schola, means "leisure". To understand what is "leisure" or "spare time", Sokobere (2011, in Krishnamurti 2011) explained that "the sense of leisure is the mind have unlimited time to observe what is happening around them and what takes place in its own right; have free time to listen, and to see clearly. Free which means that the mind is quiet, no motive, and therefore no direction. This is free, and only in this state of mind may learn, not just science, history, mathematics, but also about himself.

The words of the child friendly began to bloom use after the adoption of the rights of the child by the United Nations which was then ratified by almost all members of the United Nations in 1989. The history of the rights of children as a direct derivative of human rights was one of the long journey historical rights struggle human. After World War II, which caused the number of children who were victims, in 1979 established a working group to formulate the rights of children. The working group was then formulate the Rights of the Child which later on November 20, 1989 adopted by the United Nations and endorsed as International Law through convection United Nations, signed by the member countries of the
United Nations. According to UNICEF, Innocentty Research in words the friendy child meant guaranteeing the rights of children as citizens. While the Indonesian Children in society of child friendly defines the word of friendly means of an open society, involving children and young people to participate in social life, and to encourage the growth and wellbeing of children. Therefore, it can be said that the child friendly means placing, treat and respect the child as a human being with all his rights. Thus the friendly child can be interpreted as a conscious effort to ensure and fulfill the rights of children in every aspect of life in a planned and responsible. The main principle of this effort is the "non-discrimination", the best interests of the child, the right to life, survival and development and respect for the views of the child.

Based on the data from one of the documents of school curriculum, the Handbook Movement of Healthy School, Safer, child friendly, and exciting Junior High School, published the Ministry of Education and Culture in 2015, that, friendly is the "kindhearted and interesting minds in attitude or sweet speech and his attitude ". If this is associated with an educational institution, the child friendly school may be interpreted "as a school which upholds the rights of the child as a person who must be educated with feelings and good manners". The principle of child friendly school program is to make the interests and needs of students as the primary consideration in determining the decisions and actions taken by the management and education providers.

Another notion was also found in the book module, the child friendly school program published by the Ministry of Education and Culture that, child friendly school program is "school that consciously seeks to ensure and fulfill the rights of children in every aspect of life in a planned and responsible". The main 
principle is the interests of non-discrimination, right to life and respect for the child. Related, Senowarsito and Ulumudin (2012) who said that, child friendly school program is school based on the three principles in the learning process". The first principle of which is the provision that has meaning availability needs of the child as a love / affection, food, health, education and recreation. The second is a sense of protection who coined the protection of children from threats, discrimination, punishment, maltreatment and all forms of harassment and inappropriate policies. As well as the latter is the principle of participation. This participation is the right to act that students use to express the freedom of opinion, ask questions, argue, play an active role in the classroom and at school.

Furthmore, Karlina etc (2012) stated that, child friendly schools program has been a school culture that is reflected in the behavior of the school community by building good relations among the school community through a friendly attitude and do not use violence to the students. The teachers learned model implement of PAKEM includes universal values through motivational approaches, democratic and educates students with love.

In summary, the child friendly school program must respect students rights when expressing their views on everything, especially in science, technology, art, and culture, so that students feel comfortable and fun in the learning process at school. In addition, child friendly schools program must guarantee every student in their opportunities to enjoy the education without discrimination on the basis of disability, gender, ethnicity, religion, intelligence, and background of the parents. The child friendly schools program is also has to consider the situation of school which are safe, clean and healthy, caring and civilized environment, able to guarantee, meet, respect, rights and protection of students from violence and discrimination, on the treatment of other unnatural, and ensure the participation of students in planning, policy, learning, monitoring, and complaint mechanisms related to the fulfillment of the rights and protection of students.

How is the standard of child friendly schools program? In the manual book of child friendly schools program in Junior High School as school of documents described below, 1) every student can enjoy their rights without discrimination based on disability, gender, ethnicity, type of intelligence, religion and background of parents; 2) every student has the freedom to express views on scienc, knowledge, technology, art and culture; 3) have a curriculum and teaching methods which are friendly for students (student centered teaching) with emphasis on the values of love, compassion, empathetic, sympathetic, exemplary, responsibility, and respect for students; 4) have teachers and education personnel who are able to facilitate talent, enthusiasm and intelligence types of students; 5) have a school environment and safe infrastructure, comfortable, friendly, healthy, and clean, green, with the construction of buildings that meet the Indonesian National Standard; 6) has a school work program that considers aspects of personal growth of students; 7) have a work safety program since the students from home to school and / or safety in school; 8) each school community has a high awareness of the risk of natural disasters, social upheavals, violence and other threats against the students; 9) involving the participation of students in all aspects of school life and school activities; 10) the availability of student-oriented organizations and the development of student character; 11) the creation of a harmonious cooperation between families, schools and communities; and 12) to ensure transparency, accountability, participation, transparency of information, and enforcement of rules school. 
The furthermore, what is the legal basis of the child friendly schools program ? Based on the Constitution of 1945 Section $28 \mathrm{C}$ which stated, everyone has the right to develop themselves through the fulfillment of basic needs, is entitled to education and to benefit from science and technology, arts and culture, in order to improve the quality in their life for the welfare of mankind. The next one, the provisions of this constitution, it should be strictly regulated at the National education Act No. 20 of 20013 Article 1 that, Fulfillment of the rights of children Education is a conscious and deliberate effort to create an atmosphere of learning and the learning process so that learners in the age of the child is actively developing the potential for him to have the spiritual power of religion, selfcontrol, personality, intelligence, character, and skills needed him, community, nation and country. Operationally, also strictly regulated in Law No. 23 of 2002 Article 4 concerning the protection of children, stated that, children have the right to be able to live to grow, develop and participate fairly in accordance dignity of humanity, as well as protection from violence and discrimination. The above mentioned one of which is participation were described as the right to argue and listen to his voice. Article 9, paragraph (1) of Law No. 23 of 2002 on the protection states of child that, Every child has the right to get educating and teaching in the context of personal development and the level of intelligence in accordance with their interests and talents. Article 28B (2) of the Basic laws of 1945 stated that, every child has the right to live, grow, and develop as well as the right to protection from violence and discrimination. This provision, in operational stipulated in Article 54 of the Law on Child Protection, which stated, child inside and in the school environment must be protected from acts of violence committed by teachers, school administrators or his friends in the school concerned, or other educational institution. Article 70 Paragraph (2) stated that, every person is prohibited from treating children with neglect their views are discriminatory, including labeling and equivalency in education for children with disabilities.

The data was reinforced by data from the interviews of Mr. Slamet Muliana as a citizenship education teacher. Furthermore, based on those interviews, when he was asked whether the legal basis the implementation child friendly school was. He replied, "Constitution of 1945 Article $28 \mathrm{C}$ and Article 28B (2) as well as operationally stipulated in Article 54 of the Child Protection Act.

The next question of this study, how is the education nonviolence through implementation of child friendly school in Junior High School 3 Majalengka? The indicators of the child friendly school were: The first, the school had a child friendly school policy. The result was from the interview with Mr. Obay as the principal, Then, when he was asked, how was the embodiment of child friendly school? He replied that: school has socialized it optimum and has sticked many slogans about no cheating, no tweaking, no pinching, no kicking, no hitting and no snapping. To strengthen the response of $\mathrm{Mr}$. Obay Sobari, the reserach asked Mr. Dedi Suhendi as vice principal of curriculum areas. Based on the interview with Mr. Dedi Suhendi, when he was asked how the embodiment of child friendly schools program? He replied that the child friendly school can be realized starting with the school has a school work program that takes into account aspects of personal growth of students. Furthermore, he said strong nonviolence by the growth personality of students in school community. In fact, the growth personality of student by no mention the name of bad call, no teasing, no mocking, anti insult, not telling others to do the deed that is indecent, and not physical assault (hitting, 
kicking, and spitting). Mr. Dedi Suhendi also confirmed that, in essence is the discipline policies of child friendly schools program is without the violence.

Azim Premji Foundation (2011) suggested that, child friendly school as a concept fosters democratisation of education. It seeks to a health, hygienic, safe, and happy environment for children to learn. It is promotes classroom activities and behavior that is gender sensitive and results in effective learning. It positively incorporates the involvement of children, families, and communities in their children's schooling. Accordingly, Karlina (2012) argued that efforts made in the school program has established a child friendly school students through exemplary character, trustworthy, no punishment with violence, help and support. The Ministry of Education and Culture (2015: 65) stated that, the school needs to establish the police "no punishment with violence" for the prevention of violence in school because if it persisted actions will impact on lowering the mentality of a child such as fear, low self-esteem, trauma, anxiety, are not eager to learn, no motivation go to school, frustration, insomnia and learning difficulties. Ahmed Khan (2015) said that, child friendly school that the school helps to defend and protect all children from abuse and harm.

Based on the above description, the researcher concluded that child friendly school ensured every child and environment that were physically safe emotionally secure and psychologically enabling. Teachers should impose non-physical disiplinary measures as an alternative to beatings or cannings. Teachers could require students to write a statement describing the negative effects of their behaviour, or to apologoze for the mistake in front of the classmates. The teachers could make disipline a child by assigning non abusive physical tasks.
The second, the issue of school health service program and facilities of health care. How is the school health service program and health facilities can support the child friendly school at this school? Based on the interview with Mrs. Iis Aisyah as builder the School of Health Unit at the school, when she was asked, how was the health program implemented in school to support the child friendly? She replied that, the program was in the form of the health education and the health services.

Lawrence W. Green and Donald C. Iverson (1992: 321) reckoned that, the school health education is the combination of learning experiences initiated by personnel in the preschool, school, or college setting to develop the behavioral skills required to cope with the challenges to health expected in, and the cognitive skills required to comprehend the further learning scheduled for, the student's immediate years ahead. Centers for Disease Control and Prevention of USA (2001) recommended that, eight aspects of school health efforts to prevent unintentional injury, violence, and suicide: a social environment that promotes safety; a safe physical environment; health education curricula and instruction; safe physical education, sports, and recreational activities; health, counseling, psychological, and social services for students; appropriate crisis and emergency response; involvement of families and communities; and staff development to promote safety and prevent unintentional injuries, violence, and suicide.

Health education was the effort which given in the form of guidance to students about health covered all aspects of personal health (physicalmental and social) that grew well personality through curricular and extracurricular activities. The health education was implemented through curricular and extracurricular activities. The curricular definition is the aggregate of courses or studies given in a school. It is the applicable 
curriculum and can be integrated into all subjects or in particular subjects physical and health education.

Implementation of health education in school was done by enhancing the knowledge, skills, planting of healthy living habits, especially through the understanding of concepts related to the principles of healthy living, including: 1) to understand the pattern of healthy food; 2) to understand the needed for nutritional balance; 3 ) to understand the various sexually transmitted; 4) to recognize the dangers of casual sex; 5) to understand the various infectious diseases originating from an unhealthy environment; 6) to recognize hazard of smoke for healthy; 7) to know the dangers of liquor; 8) to recognize the dangers of drug abuse; 9) to say no in using drugs ; 10) to refuse treatment seksual.

The primary interest of health education for children is that the children have the clean and healthy behavior in life everyday and have a deterrent power against bad influences outside (drug, bad information flow, and unhealthy lifestyle). Extracurricular are those that fall outside the realm of the normal curriculum of school, performed by students. Extracurricular activities exis for all students, but the volunteer activities are not always extracurricular activities. The extracurricular activities which relate to the health education that can be done are as: the student travelling, camping, competitions, the guidance healthy lifestyle, gardening, Friday cleaning, and bulletin. The program which is effort to improve health services (promotion), prevention (preventive), treatment (curative), and recovery (rehabilitative) conducted on the students and the environment. The main objective of health services in the School program is to improve the capabilities and skills of healthy life in order to establish a healthy life. For example, the program increases understanding of the dangers of smoking, alcohol and drug abuse and prevention.
The Ministry of Education and Culture (2015: 61) stated that, the school provided medical facilities in the school, such as providing healthy school canteen, providing three bins, the bins of organic, inorganic, and B3 were representative, provide adequate infirmary along with her medications. It was relevant to the conditions in the school when the researcher saw that the school had a healthy school canteen, provided three bins, the bins of organic, inorganic, and B3 were representative, provided adequate infirmary with medicine for the first aid.

Further, The Ministry of Education and Culture (2015: 65) reckoned that, school has established program and health facilities in the child-friendly school with the indicator, such as: 1) the school had a program of health education activities carried out by the schools themselves from outsiders is necessary. Health education carried out by the builder of the Red Cross Youth in collaboration with external parties, namely the health center and police. Cooperation with the Community Health Center was a program of education on understanding the pattern of healthy food, understand the need for nutritional balance, understanding the various sexually transmitted diseases, knowing the dangers of casual sex, understanding of various infectious diseases originating from an unhealthy environment, and getting to know the dangers of smoking to health, and cooperation with police are educational programs about the dangers of liquor know, getting to know the dangers of drugs, knowing how to say no to using drugs, knowing how to reject sexual abuse treatment; 2) The school had a program of repair or improvement of health facilities, such as providing healthy school canteen, canteen honesty, available organic waste, inorganic, and trash representative is not available, have the school health room decent along her medicines; 
3) school maintained and improved the health conditions of the environment both physical environments and nonphysical environment. Organizing the physical environment include: classrooms, laboratories, school canteens, sports facilities, school principal / teacher, lighting, ventilation, toilets, showers, water supply systems in every classroom and sanitation, yard, distance whiteboard, disease vectors, tables, chairs, places of worship, and so on. School maintained and improved the condition of nonphysical environment such as familiarized behavioral dispose of waste in place, got to use the behavior of washing hands with soap and cleaned waters flow, familiarized the behavior of choosing foods healthy snacks, familiarized behavior no smoking, no community development around the school, freed of mosquito larvae and etc. There were coaching be a no smoking area. Based on the above description, the researcher concluded that in the context of the school of friendly child, this school has the established programs and health facilities at the school.

The third, the problem of school manages the environment and infrastructure. Based on observations, the researcher had turned out that school environment and school infrastructure were safe, comfortable, friendly, healthy, clean, and green, with the construction of buildings that met standards. This school is near the highway but it has a gates or fences and security system such as school security guard.

The setting of children's seats made children got clear messages about what is expected. Arranging the children's learning space gave children fell comfortable by changing the seating position adapted to the needs of the learning process. This seating is a facility needed by students for successful learning in school. Therefore, students needed seating alternative formation tailored to the needs of learning activities. An assortment of seat used in the classroom as a row to the rear which used the lecture method, and a semi-circular shape, U model, faced models, the model $\mathrm{O}$, or the model $\mathrm{L}$ were applied in learning cooperative learning. With regard to the setting of seating students in the classroom was generally no longer use the conventional model but uses models of small groups of four to six, the model of $U$, and the circle where the teacher's desk is in the middle of the group, the students were no longer separated elitist in the classroom. School gardens, mosques, libraries were also as a place of learning. With the guidance of the guardian class / teacher each class was given the freedom to organize the classroom appropriate ethical values aesthetics, providing potable water, hygiene classes familiarize work assignments, create works of art in painting the walls of the school for their designated purpose, and appreciated children's work by pasting results of children's work in the classroom. Thus, the school had been managing the environment and infrastructure which was safe, comfortable, healthy, and clean and accessible that met standar and building construction. The indicators were: 1) The convenient location of the school, the school has a gate / fence as well as other security systems, which have a security guard; 2) The arrangement of children's learning space such as by changing the seating position adapted to the needs of the learning process, for example lined up to back that used to use the lecture method, and a semicircular shape, the model $\mathrm{U}$, the model faced, the model $\mathrm{O}$, or the model $\mathrm{L}$ is applied in learning process; 3) Organizing the school laboratory space; 4) Organizing the school library space; 5) Organizing the space of school counseling; 6) Arranging of school corner for children express themselves, vent, and play with their peers; 7) The school has a healthy canteen; 8) The school sets up the trash; and 9) The school provides a toilet that meets the standard. 
Based on the above description, the researcher concluded that in the context of child friendly school, this school had been managing the environment and school infrastructure that was safe, comfortable, friendly, healthy, clean, and green, with the construction of buildings that meet the Standard. The child friendly school developed healthy and protective of children by ensures a healthy, hygienic, and safe learning environment, with adequate water and sanitation facilities and healthy classrooms, healthy policies and practices (e.g., a school free of drugs, corporal punishment, and harassment), and the provision of health services such as nutritional supplementation and counseling, provided life skills-based health education, promoted both the physical and the psychosocio-emotional health of teachers and learners, helped to defend and protect all children from abuse and harm, provided positive experiences for children.

The fourth, the issue involves the participation of students. Based on the interview to Mr. Asikin Hidayat, as principal deputy of Student Affairs, when he was asked, whether the school involving the participation of students in all aspects of school life and school activities. He said that, the students were involved in the development team of child friendly shcool, policy making, order in learning, complaints, and evaluation. He reckoned that, the students did the learning process carried out in an inclusive and non-discriminatory, an atmosphere of learning and the learning process developed the diversity of character and potential of children, the assessment carried out without discrimination. The learning process conducted in a fun, loving and free from discrimination against children inside and outside the classroom. Development interests and talents of children through extracurricular activities carried out individually and in groups. In the case of a complaint, which was available vent corner for children in the counseling room, a complaint form was easily accessible to children, and implementing a mechanism for the protection of children who made a complaint. In terms of evaluation, (a) the assessment and evaluation process based learning and promote authentic assessment, (b) the application of various models of assessment and evaluation of students' learning progress, which measures the ability of a child without comparing one with another, and to facilitate the students conducting the assessment.

The child friendly school gave the students joyfull with their rights by education without discrimination on the basis of disability, gender, ethnicity, type of intelligence, religion and background of the parents. The child friendly school also gave every student the freedom to express their views on science and technology, art and culture. Further, through the child friendly school, the school involved the participation of students in all aspects of school life and school activities.

Based on the above explanation, the researcher tried to conclude that this school had involved the participation of children in school, namely: 1) the students involved in the team development of the child friendly school; 2) the learning process conducted inclusive and nondiscriminatory; 3) the disciplinary rules drawn up with the involvement of students, representatives of parents outside the board committee and school committee and signed jointly; 4) available "vent corner" for students in the student friend counseling rooms and implementing a mechanism for the protection of students who made a complaint.

The fifth, the issue of foster noble values and cultural arts. Based on interviews by $\mathrm{Mr}$. Mahmud was as a teacher of Religion, when he was asked whether the school developed the noble values (good character) and cultural arts to 
students? He said that, the noble values and the culture arts were developed to students, for example, (a) ensure, protect and fulfill children's right to have a religion, (b) habituate greeting and shaking hands when meeting of teachers and friends, (c) habituate appreciate weakness and drawback of others, (d) habituate dispose of waste in place, (e) develop reading and writing culture as literacy school and west java reading leader's challenge, (f) develop a culture of mutual cooperation, (g) habitually do the honest attitude, (h) use the local language at least one day within one week, (i) provide access to the child to get information and improve knowledge, skills, and attitudes about the values and culture, ( $j$ ) respect the rights and duties of the foster children to exercise this right in a manner consistent with the developmental capabilities children, (k) form a learning community committed to a culture of safety and health, (l) aware of the risks of natural disasters, social upheavals, violence and other threats against girls and boys, (m) meet standards of education service minimum, (n) learn material includes respect of Human Rights, (o) include respect for the traditions and culture of the nation, (p) include a tribute to all fellow children both women and men, including children who require protection special disabilities, (q) ensure the availability of information to all parties and ensure communication and dialogue, (r) ensure the curriculum, subject matter, and picture books give a fair, accurate, informative about society and indigenous cultures. (s) ensure to provide time for the child to rest and have fun, and $(t)$ enable the cultural centers.

Based on the above data, the researcher tried to conclude that this school had grown noble values and cultural arts, namely: 1) to guarantee, protect and fulfill children's right to have a religion; 2) to habituate greeting and shaking hands when meeting teachers and friends; 3) to habituate and appreciate weakness and drawback of others; 4) to habituate dispose of waste in place; 5) to develop read and write culture (75\%), (6) to develop a culture of mutual cooperation; 7) to habituate impartiality; 8) to use the local language at least one day a week; 9) to give access to the child to get information and improve knowledge, skills, and attitudes about the values and culture; 10) to respect the rights and duties of the foster children to exercise this right in a manner consistent with the child's developmental abilities; 11) to form a learning community committed to a culture of safety and healthy; 12) to enable cultural art gallery.

The sixth, the problem of trained teachers and school administration official. Based on the interview to Mrs. Iis Rismawati as maid curriculum, when she was asked whether the school had teachers and school administration official trained? She answered yes, the school has trained teachers and education personnel. The most teachers are able to facilitate talent, enthusiasm, and kind of intelligence through intrakurikuler students, curricular and extracurricular. This was reinforced by Iis Rismawati which stated that, the child friendly school characterized by three things, namely (1) the attitude of teachers to children, (2) learning methods, and (3) classrooms. In addition, teachers play a very significant role in supplying and promoting quality of the child friendly schools program. Tsui \& Cheng (in Abdul Razak, 2008: 17) reckoned that, the quality of the profession of educators depends mainly on the teachers who carry out nearly all the task and activities of education in the school. A number of studies have shown that the quality of teaching was a major influence on student achievement (Darling-Hammond, 2000) and it had been identified by Carrol (1963) as an important variable in his model of school learning. It was not surprising that teachers was exposed to security and discussion between 
politicians, policy makers, stakehoders and parents.

The attitude of teachers to children, which is the profile of teachers against children by naked eye can be seen from the way they are dealing with children. Teachers as a friend to children should be able to demonstrate the behavior fair to all children regardless of their social status or physical condition of the children, both normal and special needs children and to respect the rights of the child. Compassion for all children, apply religious norms, and the prevailing culture. Regarding the method used in school lessons, Carrol also said that, the learning of friendly for students with emphasis on the values of love, compassion, empathetic, sympathetic, exemplary, responsibility, and respect for students.

This is in accordance with what is prescribed by the UNICEF on the scholls of friendly child as businesses that are focused on the process in the classroom and school environments to promote more "learning fun", exposes the child to the learning process very participatory in an environment rich-source power guided by teachers trained to become "friendly" facilitators. Students are not only confined in the classroom, but also studied in an open space with a variety of learning models and packaged in exciting activities and educational games. Learning culture must be the "adventure of a lifetime" and "exploratory journey without end", so that the growth of the whole personality is integrated with the values learned. Thus the "learning" will be most meaningful and capable of individuals printing quality. Thus, that school has teachers and education personnel who are trained, namely: 1) the attitudes of teachers is fair and wise to respect the rights of children, that is. the teacher as a friend to children showing behavioral fair to all children regardless of their social status or physical condition of the child, as well as respecting the rights of the child.
Teacher showing affection towards children, apply religious norms, and the prevailing culture; 2) methods of active learning, innovative, creative, effective and fun. Based on the above explanations, the researcher tried to conclude that this school had professional teachers and school administration efficia.

Based on the data above, the researcher tried to conclude that child friendly school developed the effective of learning as promotes good quality teaching and learning processes with individualized instruction appropriate to each child's developmental level, abilities, andlearning style and with active, cooperative, and democratic learningmethods. Providing structure content and good quality materials and resources, it enhanced teacher capacity, morale, commitment, status, and income and their own recognition of child rights, promotes quality learning outcomes by defining and helping children learn what they need to learn and teach them.

The seventh, the issue of program safety in the school. Based on interviews with Mrs. Tati Suprapti as a science teacher, when she was asked whether the school has a safety program for students, she said, the school has a safety program in school. Furthermore she said that, the general school community has a high awareness of the risks of social disaster, violence, the risk of natural disasters and other threats to the students. Mrs. Mimin Suminar as a social teacher added that, every school community has awareness against the risk of a variety of disaster. The school made some efforts, for example: 1) introduce definite types of disasters that often occurs in school such as traffic accidents, natural disasters, kidnapping, and violence; 2) create awareness to the citizens of the school if there is something or look at adverse events in the school must report to the teacher on duty or security guards; 3) provide guidance on regulations while in the school environment; 4) guide the school 
community to escape in case of fire or other disaster; 5) guide the school community to use the equipment in case of disasters; 6) take safety measures to avoid a catastrophic accident. From the dimensions of infrastructure, schools provide infrastructure facilities related to safety of life such as a lightning rod and firefighters.

Based on the above explanations, it can be concluded that the school had established safety program in schools, they were: 1) the school socialized the types of disasters that often occured in the school environment; 2) creating awareness to the citizens of the school if there was something or looked at adverse events in the school must report to the teacher on duty or security guards; 3) providing guidance on regulations while in the school environment.

The eighth, the issue of the school involved the participation of the community and the business in the realization of child friendly school. Based on the interview with $\mathrm{Mr} \mathrm{H}$. Sukiman, while asked whether in the context child friendly school involves the participation of the community and the business world in the school. He replied that, the role of society grown, developed, and maintained by the school for their problems and challenges faced in schools in an effort to provide service of quality education. Furthermore he said that, the cooperation such as: a) develop the participation of parents in guiding children by providing 20 minutes a day to communicate and listen to the stories of children during the school day; b) conduct regular meetings between parents and teachers to discuss the child's development; c) the cooperation with related organizations such as health centers and police force, both for the business world and the learning process for children's creativity; and d) family joins communities that support their children in learning, monitor, and disseminate the implementation of child frienly school. This is in accordance with what is stated by the minister education and culture (2015: 15) that, one of the child friendly school standard is the creation of a harmonious cooperation between families, schools and communities. Furthermore, UNICEF also stated one of the characteristics of the child friendly school, it was, reflect and realize the rights of all children in collaboration with other partners to promote and monitor the welfare and rights of all children; defend and protect all children from abuse and danger, both inside and outside of school. rekoned that, involves with children, families, and communities, family-focused working to strengthen families as the child's primary care givers and educators and helping children, parents, and teachers establish harmonious relationships, community-based encouraging local partnership in education, acting in the community for the sake of children, and working with other actors to ensure the fulfillment of childrens' rights.

Based on the above explanations, it could be concluded that this school included community and the business world in school, namely: 1) the participation of parents, community organizations, and companies in implementing child friendly school; 2) empowers the institutional role and the school community in efforts to achieve child friendly schools; 3) conduct cooperative with related agencies such as health centers and police, business / industry to contribute through corporate social responsibility or corporate social responsibility in the field of education; 4) regular meeting between parents and teachers / homeroom to discuss students' progress; 5) invites families to join in a community that encourages students to learn, monitor, and disseminate the implementation of child-friendly school. 


\section{Conclusion}

Education nonviolence has established the education for a culture of peace to create and encourage peace in the minds of the students based on the universal values of respect for life, liberty, justice, solidarity, tolerance, human rights and equality between them. The effort of education nonviolence is to create a culture of peace and nonviolence for the children. Education nonvolence's effort is also to prevent social conflict and to promote the fundamental values of all societies without seeing barriers cultural, religious, racial, group, and others.

Child friendly school builds the education nonviolence. A child friendly school is a school that recognizes and nurtures the achievement of children's basic rights. Child friendly school work with all commitment holders, especially parents/guardians of students in the development of a learning environment for children and effective learning quality according to the children's current and future needs. The learning environments of child friendly school are characterized by equity, balance,freedom, solidarity, non-violence and a concern for physical, mental and emotional health. These lead to the development of knowledge, skills, attitudes, values, morals so that children can live together in a harmonious way. A child friendly school supports children for development and a school-friendly community.

Child friendly school developes the effort of an environment of good quality charateristic with: (1) inclusive of children as does not exclude, discriminate, or stereotype on the basis of difference, provides education which is free and compulsory, affordable and accessible, especially at the risk families and children, respects diversity and ensures equality of learning for all children (e.g.,girls, working children, children of ethnic minorities and affected by HIV/AIDS, children with disabilities, victims of exploitation andviolence), responds to diversity by meeting the differing circumstances and needs of children; (2) effective of learning as promotes good quality teaching and learning processes with individualized instruction appropriate to each child's developmental level, abilities, and learning style and with active, cooperative, and democratic learning methods. Provides structured content and good quality materials and resources, enhances teacher capacity, morale, commitment, status, and income and their own recognition of child rights, promotes quality learning outcomes by defining and helping children learn what they need to learn and teaching them how to learn; (3) healthy and protective of children by ensures a healthy, hygienic, and safe learning environment, with adequate water and sanitation facilities and healthy classrooms, healthy policies and practices (e.g., a school free of drugs, corporal punishment, andharassment), and the provision of health services such as nutritional supplementation and counseling, provides life skills-based health education, promotes both the physical and the psycho-socio-emotional health of teachers and learners, helps to defend and protect all children from abuse and harm, provides positive experiences for children; (4) gender sensitive by promotes gender equality in enrolment and achievement, eliminates gender stereotypes. Guarantees girl-friendly facilities, curricula, textbooks, and teaching learning processes, socializes girls and boys in a nonviolent environment, encourages respect for each others' rights, dignity, and equality; (5) involved with children, families, and communities, family-focused working to strengthen families as the child's primary care and educators and helping children, parents, and teachers establish harmonious relationships, community-based encouraging local partnership in education, acting in the community for the sake of children, 
and working with other actors to ensure the fulfillment of children's rights

Education nonviolence trough implementation of the child friendly school in Junior High School 3 Majalengka in West Java showed the following results: 1) The school had a child friendly school policy; 2) The school had a health program and facilities of health care; 3 ) The school had the safe, comfortable, healthy, clean, accessible environmental and the complete infrastructure; 4) The school involved the participation of children; 5) The school developed values, cultural and arts; 6) The school had the professional teachers and school administration officials; 7) The school had a safety program; and 8) The school involved the participation of the community and the business.

\section{Refrences}

Adisusilo, S. (2011). Learning ValuesCharacter: Jakarta: Grasindo.

Budimansyah (2010). Strengthening Citizenship Education to Build Nation Character. Bandung: Widya Script Press.

Centric For Disease Control and Prevention (2001). School Health Guidenles To Prevent Unintentional Injuries and Violence. USA Accessed https:// www.cdc.gov/mmwr/preview/mmwrhtml/ rr5022a1.htm.

Creswell, J.W. (1994). Research Design Qualitative and Qualitative Approach. London: Publication.

Elfindri, et al. (2010). Soft Skills For Educators, Padang: Bauduose Media.

Kris, et al. (2011). Identifying Model Child Friendly Schools (CFS) unit level early childhood education districts throughout South Semarang. Research journal PAUDIA, 1(1), 2011.
Kunaepi, A. (2012). Internalization of Islamic Education and Religious Culture, Nadwa Islamic Education Journal, 6(1), 2012.

Lawrence W Green and Ronal C. Iverson (1982). School Healt of Education, Washington DC.

Lickona, T (1992). Educating For Character. New York: Bantam Books.

Moleong, LJ (2007). Qualitative Research Methods. Bandung: Rosda paper.

Mulyasa. (2012). Management Of Character Education. Bandung: Alfabeta.

Razak, A., N. (2008). Conceptualisation Of Teacher Commitment As Multidimentionel Construct, International Journal of Education, 3(1) 17-33.

Sapriya. (2007). Expert perspectives Thought About Civics InNation Character Development. (Dissertation). Graduate School, Indonesia University Pendidikan Indonesia, Bandung.

Senowarsito and Ulumuddin A. (2012). Implementation of the Education for child friendly To Buld Character Students at State Elementary School in the city of Semarang. Media Education Research. 6(1).

Sigit. (2010). Importance of Anti-Violence Education For Children go to school Primary In Brought the Good Citizen. Informasi: Kajian Ilmu Komunikasi 1(1). http://dx.doi.org/10.21831/informasi.v1i1 .5665 .

Slam, Z. (2015). Integrative Learning SkillBased Soft and Hard Skill. Jakarta: UIN Syarif Hidayatullah. 
Suharno, et al. (2013). Model Peace Building Teaching and Learning: An Intervention Violence Prevention through Formal Education. http://eprints.uny.ac.id/23718/ 1/Artikel Strategy. Accessed January, 20, 2017.

The Ministry of Education and Culture. (2015). Healthy Schools. Friendly Children and Fun. Jakarta: The Ministry of Education and Culture.

The Ministry of Education and Culture (2016). Movement Guidance Child Friendly School, Junior High School. Jakarta: The Ministry of Education and Culture.
Tilaar. (2002). Social changes san Culture. Jakarta: Grasindo Constitution of the Republic of Indonesia Year 1945 Results Amendments

Winataputera (2012). Civics Education in Perspective For Life Feeding the Nation. Bandung: Widya Script Press 